\title{
Journalism, journalism education and a region's integration The case of Southeast Asia
}

\begin{abstract}
The 50-year-old Association of Southeast Asian Nations (ASEAN) is now in its third year implementing the mechanics of regional integration. How does this region-wide development affect journalism in individual countries and in the region? This qualitative research sought to find out the meaning and implications of regional integration to journalism practice and education in Southeast Asia. There is enthusiasm over developing a model on 'ASEAN-centered journalism and journalism education', however there are country-level realities that news organisations and journalism schools face before proceeding to even attuning reportage and journalism instruction to the needs of ASEAN.
\end{abstract}

Keywords: ASEAN, Association of Southeast Asian Nations, journalism education, journalism practice, journalism models, Philippines, regional integration

JEREMAIAH M. OPINIANO, AIRA L. BAGTAS, KARL C. BASCO, RAPLH J. HERNANDEZ, ELYSSA C. LOPEZ, MICHAEL C. RODOLFO and ANNE K. VICHO University of Santo Tomas, Manila

\section{Introduction}

EGIONAL integration by countries reflects the influence of globalisation. Regionalisation of economies helps aggregate resources and politically positions the region - and the countries that belong to it - in the league of nations. Such was the vision of the European Union when most of Europe's countries integrated in the early 1990s. The Association of Southeast Asian Nations (ASEAN), grouping ten economies, is the latest regional bloc to join the trend. (ASEAN was formed in 1967 with five countries, which expanded to include a further five.)

ASEAN operationalised regional integration recently to fulfill an agreement in 2007 for the region to become an 'ASEAN Community' by 2015. Regional integration is largely motivated by a region's economic potential, what with 
ASEAN having a combined economic output of US\$2.2 trillion or a quarter of world trade (Salvosa, 2014). ASEAN economic integration can transform the region into a potentially influential single market and production base that other economic blocs can take note of.

Given this development that also affects individual countries, what about journalists and journalism schools: Should they 'regionalise' as well? How can Southeast Asia's news media and journalism schools work together - for professional and academic networking objectives - given political-cultural diversity and the prevailing media environment and press freedom conditions in individual ASEAN countries, 'from the freewheeling to totalitarian to something in between' (Chongkittavorn, 2002)? Given the diversity of journalism in ASEAN countries, and with journalists within ASEAN countries serving either the public or their nations' leaders (Chongkittavorn, 2002), how can regional 'integration' by ASEAN news media be made possible?

Regionalisation of both journalism and journalism education thus provides an interesting research question. To what extent are students taught and trained to report on the wider region? To what extent are affairs of neighboring Southeast Asian countries reported in individual ASEAN member-countries' news media? These questions are asked in a region wherein the free press and journalism's roles in individual countries have their own challenges. In recent years, some individual ASEAN countries have come to regard democracy as problematic (especially Myanmar and Indonesia), although it is not easy for journalists to stamp their editorial independence and be monitors of power within their countries. Yet seeing how journalism can be a force for regional-level freedom of expression (even if they come from countries where this freedom is shut out or is being challenged) is a prospect.

Looking at the bigger picture, however, with observations such as a lack of 'ASEAN identity' and limited awareness on ASEAN integration (ASEAN Secretariat, 2013) on the background, how will these factor in the desires of journalists and journalism schools to work together under a milieu of regional 'integration?' What about the observations on the way the ASEAN conducts itself as a regional bloc: how will journalists report ASEAN and its membercountries - as a voice of their respective governments, or as advocates for press freedom and security of journalists in semi-authoritarian ASEAN members? Meanwhile, ASEAN aspires to create a 'common identity' by the year 2020 amid the mosaic of identities, cultures and ethnicities within the region (Jönsson, 2008). Even if this 'common regional identity', however, remains unclear (Jönsson, 2008), his journalism and journalism education poised to address this identity-building issue under ASEAN integration?

This qualitative research is structured according to the following outline: First, the article will give a literature review on regional integration - to include 
ASEAN integration - and on how the news media and journalists operate under the ambit of regional integration. Second, the state of journalism, journalism education and press freedom in ASEAN will be provided as contexts. Third, views from journalists and journalism educators will be presented. Finally, the implications of these views to research and practice on journalism and regional integration will be discussed.

\section{Literature review}

A. Media and regional integration: The pre-internet McBride Commission (1980, in Churchill, 1991) carried a definition of media integration:

The provision to all persons, groups, nations of access to the variety of messages which they need in order to know and understand each other, to appreciate other's living conditions, viewpoints and aspirations. (Churchill, 1991)

In this kind of integration, harmonising media policies and news content are priorities so as to create a common media culture and provide people with the right to be informed (Churchill, 1991). The Commission that time thought of 'shifting national media loyalties to larger entities, establishing and maintaining an information community, or even harmonising media policies among countries' (Churchill, 1991, p. 19), and yet cultural, socio-economic and political nuances in a geographic region are understood. However, given the internet and social media, news and information have speedily traveled and geographic boundaries have tumbled; people receive news and information from various sources.

For economies integrating regionally, the media may have to be included as a stakeholder in promoting integration and making their public understand this process. However, regional identity and building such an identity remain unclear. In ASEAN, for example, the region is said to be a community that is 'rule-based' rather than 'identity-based', with almost nil evidence of a collective regional identity that is based on 'shared meaning structures, mutual identifications and norm compliance within the 'ASEAN way'. Even differences in values and political systems hamper the building of this regional identity. Individual countries still remain concerned about state sovereignty and domestic stability, or even national security and macro-economic progress (Nischalke, 2002).

A region that can provide lessons on regional integration and the media is the European Union. (Although, the Brexit vote of 2016 and United States President Donald Trump's 'America First' agenda are challenging regional integration.) Russ-Mohl (2003) thinks having a 'European journalism' is improbable and impossible given language barriers between and among countries. European journalists speak their local languages and operate within their locally-centered 
professional groups. EU is even deemed to be 'elitist' given that it is always leaders who are talking (Russ-Mohl, 2003).

While media outfits in the EU may have structured 'EU news' as important, the problem lies in how often EU news is presented (Peter \& de Vreese, 2004). This leads to lukewarm support from constituents to news stories about the European Union; the regional body's limited efforts on external communication are even to be blamed. African countries and their journalists meanwhile also encountered difficulties integrating given their cultural diversity, given a wide variety of public interests, and given prevailing politics (Churchill, 1991).

For bodies working on regional integration, the natural course of action was the staging of awareness-raising workshops on regional integration by regional intergovernmental bodies, targeting journalists. This was seen, for example, in the Caribbean Community and Common Market (CARICOM) (Nevis Pages, 2014).

B. Journalists and regional integration: Even before the trend of regionalising countries and economies, journalists from integrated regional communities have established regional associations for their respective members of the media. Examples include the Eastern African Journalists Association for Eastern African Community (EAC); Southern African Journalists Association for Southern African Development Community (SADC); Journalists for Regional Integration (JORIN) for the Economic Community of West African States (ECOWAS); and the Association of Caribbean Media Workers for (ACMW) for CARICOM. These organisations aim to foster camaraderie among the journalists and develop media practice across the region. Eventually, these groups were pushing for issues like greater press freedom, better work conditions for journalists, and journalists' safety. The Accra-based JORIN, for the ECOWAS region, seemed to be explicit in saying that the group is 'campaigning to fast-track the economic and political integration of the sub-region' (JORIN's website at http:// integrationreporters.com/).

In some regions, however, there are some issues cropping up. For example, since journalists from CARICOM are among the skilled workers to freely move, regional officials disregarded the idea of CARICOM licensing the journalists (Stabroek News, 2009). Even skills certificates that may be honoured in other countries within CARICOM are disregarded by some journalists (Williams, 2010).

Regional bodies pushing for integration have also been platforms for regional journalism groups to push for advocacies related to freedom of the press and freedom of expression. This is seen in the ECOWAS region (Article 19, 2012). Regionalism had also helped some journalists to form groups covering the same beat, such as science journalists from countries under the EAC (SciDevNet, 2012). Some journalism educators, for example in the Southern Africa Development Community (SADC), have also explored the possibility of 
regionalism helping to harmonise journalism education while leaving space for cultural diversity (Sibanda, 2010).

C. Studying journalism and regional integration: Some studies, such as surveys and content analysis, have been done on news coverage on regional integration, including how journalism influences public opinion on integration. One can observe that since regional integration covers various countries, the quality and depth of the news coverage vary depending on the news media outfits' editorial policies, target policies, or media ownership and management. Thus regional-level media coverage, say for example East African issues as one beat, remains disparate and centered on national concerns (Nyabuga in Society for International Development, 2011).

The studies reveal that the news media's coverage of regional integration can influence audiences in individual countries. Vliegenthart et al (2008) found a relationship between news media coverage and citizens' attitudes toward the European Union, as tone of the coverage and framing of EU policies affect audiences' support for the EU. Carey (2004) found that the British press' 'highly partisan and biased' coverage exerted both positive and negative influences, even as audiences' attitudes toward the EU were more dependent on party preferences. Again with the reportage in the United Kingdom and British audiences' public opinion, Dursun-Ozkanca (2011) found the news media has transferred their own set of salient issues to the British audience.

The themes of these regional stories are obviously economic. Cauwenberge et. al. (2009) found that the economic consequences of regional integration are the leading news frame in four European newspapers' coverage of the EU Constitution. However, how do regional stories go side-by-side with local stories? The regional news stories, in one study, are 'simply irrelevant' compared to stories from the established national news media outfits (Russ-Mohl, 2003). As to the newsworthiness of EU news reports, there is 'high visibility' during key EU events and 'low visibility' during ordinary periods (de Vreese, 2001).

Heikkilä and Kunelius (2006) went against the tide of quantitative research and did qualitative interviews with journalists from ten EU countries. The interviews led Heikkilä and Kunelius to develop four quadrants covering the varying perspectives of how journalists approach covering regional stories (contextualised in the case of the EU). These perspectives can serve as a preliminary theory or framework on media and integration (kindly see Theoretical Framework section).

The themes of previous researches on journalism, journalism education and regional integration have covered the following: analyses of region-wide reportage vis-à-vis public opinion (Vliegenthart, 2008; Dursun-Ozkanca, 2011) and vis-à-vis local stories (Russ-Mohl, 2003); a continent's views on another continent's efforts at regional integration (Chaban and Holland, 2008); and the 
state of journalism/communication education in regions (Maslog, 1990; Hwa and Ramanathan, 2000; Sibanda, 2010; Skjerdal and Ngugi, 2007; Terzis, 2009). Thus, this current paper will attempt to weave the links between regional integration and conditions of journalism, journalists and journalism education in individual countries as these relate to a greater region.

\section{Theoretical framework}

Heikkilä and Kunelius (2006), from interviews with 149 journalists from 10 European countries, developed a model on journalists' professional imaginings on a regional public sphere (in this case, the European Union). The authors found three discourses on EU journalism: classical professionalism, secular news discourse, and cosmopolitan discourse.

The nation-state is the locus of the classical professionalism discourse, as journalists under this discourse pursue the common good (similar to the "national interest"). Journalists under classical professionalism are detached observers, neutral mediators, or critical commentators. Readers of these journalists' stories are informed citizens and national communities. As found by the researchers to expound on the classical professionalism discourse, journalists point to the EU's political problems (lack of efficacy and popular support) and communication problems (lack of transparency, manipulation, and EU propaganda).

The secular discourse, for its part, is more consumer- or market-driven, concerned with everyday life and the 'realm of meanings.' This discourse is dependent on public opinion, utility, and pleasure, as journalists here function as 'consultants' or whistleblowers. The implied readers for such stories carrying a secular discourse are apolitical news consumers. Applying the secular discourse, journalists who answered to Heikkilä and Kunelius also found different political problems (intangibility of EU politics and the consequences of EU policies) and a communication problem (alienation of EU elite).

Finally, the cosmopolitan discourse is 'shaped by emerging supranational trends in international politics and business'. This transnational approach is something foreign affairs journalists prefer; the approach caters to elite audiences using the 'need to understand others' and 'future orientation' as news frames. Journalists here are experts, educators, 'citizens of the world'. Journalists here found the EU's political problems like lack of political dynamism, problems in the enlargement, and relating to the rest of the world. Meanwhile, the incapacity to communicate European values is the communication problem found by journalists under the cosmopolitan discourse.

Heikkilä and Kunelius then developed a model that has four quadrants (Figure 1). The classical professional and cosmopolitan perspectives occupy the top two quadrants, as both are oriented toward the 'horizontal' function of political communication (which concerns the interaction between institutional actors). Meanwhile, 
the secular perspective and a fourth 'perspective' ('cosmopopular', wherein the $\mathrm{EU}$ is covered from a transnational perspective but is not pitting member-nations over one another) are at the bottom quadrants - leaned toward 'vertical' function that concerns the relationship between citizens and those in power. The left-hand quadrant (classical professionalism, secular) see journalists oriented towards nationalism, and the right hand quadrants (cosmopolitan, 'cosmopopular') lean journalists toward nationalism.

In a sense, Heikkilä \& Kunelius (2006) gave a context of journalists' perspectives to cover a region like the EU. This considers the editorial dispositions of journalists originating from a geographic region and those outside of that region in their approach to events and news coverage. This paper builds from this model and looks into operational measures of how a geographic region's journalists (as well as journalism schools) consider reporting about Southeast Asia under the ambit of regional integration.

\section{Figure 1: Journalists' professional perspective model}

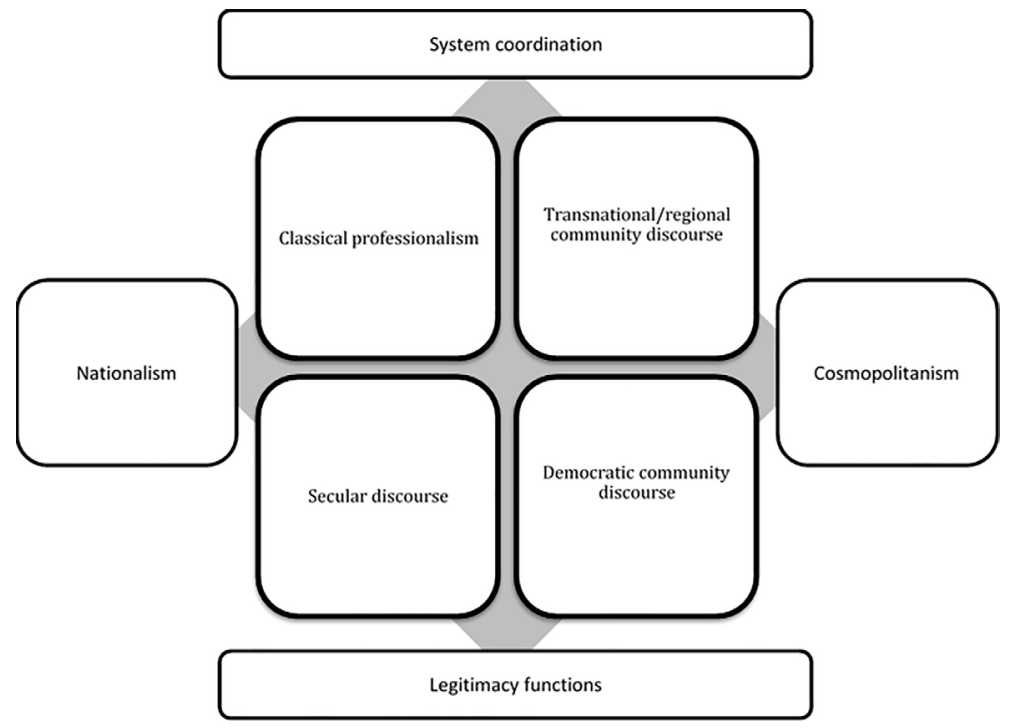

Note: This matrix provides a context in a regional (European) public sphere such as European Union (Heikki Heikkilä \& Risto Kunelius, 2006)

\section{Methodology}

This qualitative research sought to find out the meaning and implications of regional integration unto journalists and journalism educators in ASEAN. Interviewed here were four journalism professors (two from Indonesia, one each from Laos and Vietnam) and five journalists (two from the Philippines and one each from Indonesia, Singapore and Thailand). Researchers from the 
Philippines reached respondents via electronic mail and face-to-face visits. Researchers targeted to get at least one journalist and one journalism educator in each of the ASEAN member-countries but only a few responded. Even those who initially said yes did not respond to interview requests anymore. Using English as the method of communicating also seemed to intimidate the respondents, except for respondents from Singapore and the Philippines. (Even if an ASEAN-wide conference of journalism educators, held in December 2014 in Manila, was an avenue to ask for respondents, those who agreed to respond did not eventually answer the researchers' questions.)

The themes of the questions covered the following: a) The meanings of 'ASEAN integration' according to respondents; b) Reporting about ASEAN and ASEAN identity; c) Roles of journalists and journalism schools in reporting about ASEAN and its member-countries; d) Views on regional integration vis-à-vis integration efforts by journalists and journalism schools; and e) Challenges of doing region-centric journalism practice and journalism education.

\section{Contexts}

A. ASEAN integration: On December 2007, in Cebu City, Philippines, the Association of Southeast Asian Nations (ASEAN) set a bold goal to achieve regional integration by 2015. ASEAN envisioned a single market and production base resulting in a highly-competitive economic region that is fully integrated into the global economy. The root of such efforts at regional integration is the ASEAN Charter that seeks to promote a "common ASEAN identity and a sense of belonging among its peoples in order to achieve its shared destiny, goals and values' (ASEAN Secretariat, 2008).

ASEAN Integration is banked on three pillars: The ASEAN Political-Security Community (APSC), the ASEAN Economic Community (AEC) and the ASEAN Socio-Cultural Community (ASSC). Of interest here are the AEC and the ASCC (the latter aims to "nurture human, cultural and natural resources for sustained development in a harmonious and a people-centered ASEAN').

Essentially, the thrust of ASEAN integration is harmonisation and cohesion of activities, policies and programmes of member-governments. This harmonisation will be made evident in arenas such as trade (AEC) and education (ASCC). AEC will also see entrepreneurs in the region compete against each other for a regional-wide market.

However, the differing histories, beliefs, values, levels of development, and political systems in Southeast Asian countries have made regional integration more difficult to comprehend. ASEAN policy makers have also been criticised as being 'elitist and high-handed', with a lackadaisical attitude toward soliciting public opinion. This is not to mention the usual perception of policy analysts on ASEAN: meetings by ASEAN leaders as usually 'talk-shop', filled with efforts 
that stress much on achieving consensus and on defending national sovereignty. There is also the observation of ASEAN not building 'stronger institutions' like the European Union - and thus, 'initiatives to build real cooperation, or to bring (about) change to a specific ... ASEAN country, are inevitably ineffective' (Milner, 2012). A democratic deficit among other member states also factors in as constraint in the progression of ASEAN's goals. The more ASEAN claims and tries to transform Southeast Asia into a community, the more the Association may be challenged by questions about democracy.

B. Journalism and media in ASEAN: There is unequal media development in ASEAN (Löffelholz \& Arao, 2011). This is owing to the differing media systems in member-countries, with countries' political systems impacting on media freedom and independence in those countries (Konrad Adenauer Stiftung, 2015). One has to take into account ASEAN member-countries' highly-diverse political systems - from democratic and transitioning societies such as the Philippines, Indonesia and Myanmar to highly repressive, single-party regimes such as Laos, Cambodia and Vietnam (Reang, 2014).

In general, ASEAN member-countries' media is not always free (Chongkittavorn, 2002, 2011a, 2011b; Löffelholz \& Arao, 2011; Arao, 2008). Assessments and surveys of press freedom and media, with Southeast Asia as geographical focus, reveal the challenges that remain in member- countries' individual media environments. An insightful analysis comes from Freedom House which has been tracking countries' freedom of the press (or media independence) for decades. Looking at two decades of Freedom House's Freedom of the Press Index, most of the ASEANmember countries' press freedom conditions are 'not free' (Figure 2).

The latitude of freedom of expression and right to information varies by ASEAN member-country in consideration of their 'politically, socially, economically and religiously disparate' conditions (Reang, 2014). The range of press freedom conditions in ASEAN member-countries, as made evident by the Freedom House surveys' scores, is uneven: from the Philippines that is 'partly free' to Laos where news media outlets are controlled by the government. Countries such as Cambodia and Thailand also find negative reporting on their monarchies as apprehensible since this will compromise the culture of these countries (Löffelholz \& Arao, 2011).

Seven of the 10 ASEAN member-countries have enacted press laws that are different from media licensing laws. However, these press laws differ in approach - from Indonesia's 1999 law that defines and protects journalistic work from state intervention and harassment, to Laos' and Vietnam's laws that see the news media as propaganda arms of the government (Southeast Asian Press Alliance, 2015). Beyond media laws, ASEAN member-countries' journalists continue to confront media impunity - especially the Philippines.

Government leaders have also felt the pressure of an active citizenry who voice their comments on policies in social media (the backdrop here is growing 


\section{Figure 2: Freedom House press index, 1993-2014}

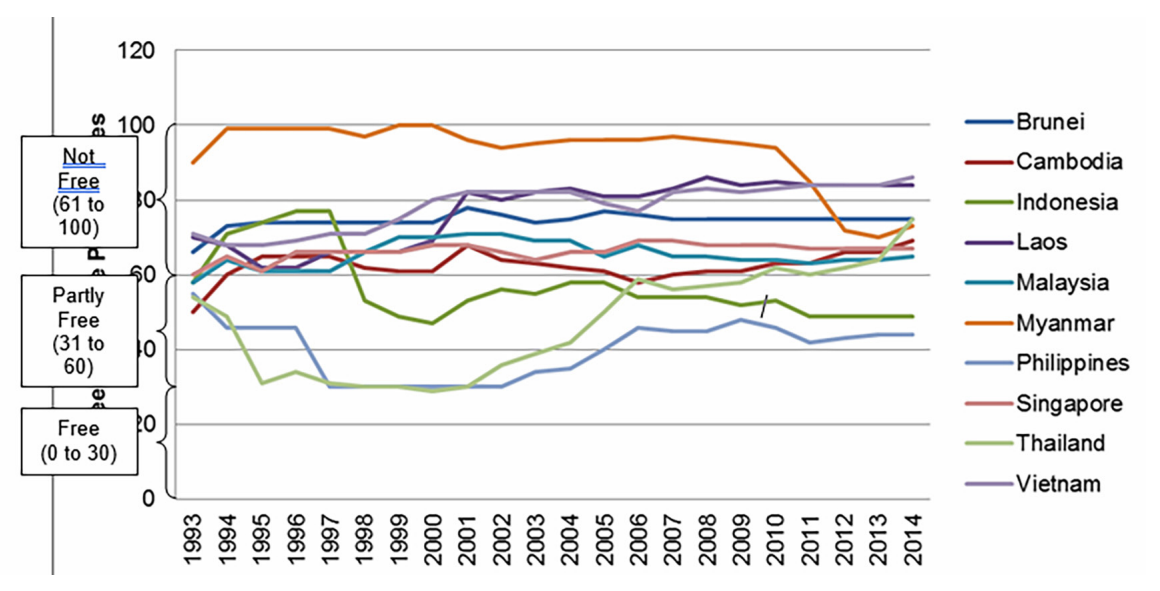

Source: Freedom House, 2015. Note: The lower the score, the freer the country's freedom of the press.

internet penetration by Southeast Asian countries). Apart from warnings issued by state leaders on voicing out criticisms online, websites are being blocked or put under surveillance. 'Investigative bloggers and cyber-dissidents' are even investigated. Some ASEAN member-countries' prospective and actual internet laws and regulations were even seen as threats to freedom of expression and internet freedom, citing the cases of Laos, Indonesia, Cambodia, Malaysia and Thailand (Konrad Adenauer Stiftung, 2015).

These challenges facing journalists and the media in Southeast Asia are despite the fact that digitisation, privatisation of media and increased accessibility of news have all transformed the media landscape of the greater Asian continent. This means that there had been a 'substantial increase in the production, consumption and distribution of media... contributing to greater pluralism' (Konrad Adenauer Stiftung, 2015).

The Southeast Asia Press Alliance (SEAPA), a network of media development and journalists' organisations in Southeast Asia, summed it up best in describing the situation facing journalism and the news media in the region:

Overall, the media situation in Southeast Asia remains largely where it is: countries with relatively freer media remain beset with the problems of impunity for violence and politics-related control through threats and lawsuits.

On the other hand, those with restricted media environments remain unchanged as their politics. There may be little overt censorship reported because control has been institutionalised through self-censorship by media houses or individual journalists who do not wish to risk their professions, safety or freedom. (SEAPA, 2015) 
C. Journalism and media's role in ASEAN integration: Media's role in ASEAN integration is lodged under the ASCC pillar. The ASCC carries the vision of '....achieving enduring solidarity and unity among the nations and peoples of ASEAN by forging a common identity and building a caring and sharing society' (ASEAN Secretariat, 2009). The problem, however, is people's limited awareness about ASEAN and ASEAN integration. The ASEAN Secretariat's own survey (2013; also in Salvosa, 2014) itself revealed that while 81 percent of survey respondents located in member-countries' capital cities were familiar with the name 'ASEAN', three-fourths of respondents lacked a basic understanding of the ASEAN Community.

The ASCC pillar document of the ASEAN Secretariat then gives media the role of propagating awareness of ASEAN and promoting a sense of community in the region. This includes producing media materials on ASEAN, increased media exchange and networking of ASEAN's communication personnel, and engaging the mainstream media in promoting all ASEAN programmes and projects (ASEAN Secretariat, 2009). Banking on the media becomes logical because the ASEAN Secretariat's survey (2013) showed that the number one source of information of respondents about ASEAN is television (78.4 percent), school (73.4) and newspapers (70.7).

Such is why ASEAN journalism organisations, for example, have been organising events that have cited the role of journalists in regional integration. Training activities and handbooks for journalists surrounding the work of ASEAN, ASEAN integration and experience of regional integration followed suit (Löffelholz \& Arao, 2011). There have also been regional-wide alliances of journalists in ASEAN, some of which were created prior to the 2007 signing of the ASEAN Charter in Cebu City, Philippines. Veteran alliances such as the Southeast Asian Press Alliance (SEAPA) and the Confederation of ASEAN Journalists (CAJ), and young networks such as the Southeast Asia Journalists Union (SEAJU) and the ASEAN Journalists' Club, had been formed. (Even an idea to form an ASEAN Press Council was floated [Lim, 2013], with the 'integration' of media personnel from ASEAN member-counties in mind.)

However, there is a perceived lukewarm reception to journalists in ASEAN. Even with the over-three decades that the CAJ had been formed, the ASEAN itself was said to have done little to promote solidarity and cooperation between journalists within the region, 'let alone media freedom and professionalism' (Chongkittavorn, 2011b). ASEAN's interaction with journalists may be more for exchange visits and views on non-sensitive issues, taking note of the noninterventionist, non-interference nature of ASEAN member-countries (Chongkittavorn, 2011b). Not surprisingly, it is observed that ASEAN journalists report on their own countries and many journalists within ASEAN countries are tied to the nature of their press systems and government control. Issues such as the 
territorial disputes between some Southeast and East Asian countries and China, and the Rohingya refugee crisis, has seen Southeast Asian newspapers criticise the ASEAN for not acting on these issues as a solid bloc (Deutsche Welle, 2015).

Chongkittavorn (2002), a veteran Thai journalist, succinctly wrote this observation on ASEAN journalists that can perhaps be the trajectory for Southeast Asian journalists' place in regional integration:

In general, journalists in ASEAN seldom write about, let alone analyse, the organisation as a whole. Most written reports, when they appear, are parochial and narrow, focusing on bilateral relations - which country gets from what and whom. It is ironic that most reports and analyses about ASEAN as a group come from wire services and foreign journalists. ASEAN journalists still do not appreciate the organisation's [ASEAN's] values, strengths and bargaining power.

While ASEAN leaders and senior leaders hail the... arrival of the ASEAN community in 2015, very few journalists bother to ask how we are going to get there. Can a so-called 'people-oriented ASEAN Community' be attained without active media participation and understanding? How many journalists have read the key documents that made the grouping what it is today? The implication is obvious: There can be no community if there is no media involvement. (Chongkittavorn, 2002)

Inter Press Service (2014) did a content analysis of the stories $(\mathrm{N}=1,882)$ in major ASEAN member-countries' newspapers (English and local language) on ASEAN, published in months when there is the ASEAN summit and on ordinary months. Spanning the years 2009 and 2010, the results revealed that the most number of stories were spot and straight news; were about 'territorial disputes and conflict, foreign affairs and diplomacy'; had government officials, politicians and diplomats as the most-cited sources; were written by staff journalists of the major ASEAN newspapers; were mostly found in the 'other inside pages' of the newspapers and were text-only stories with no accompanying visuals; were of medium length (25-to-50 column centimetres); and were mostly not related to any ASEAN event/summit/meeting. This content analysis research gives us a glimpse of the prominence of ASEAN as a beat, giving hints if regional integration will lead to increased numbers of stories or not.

The news media organisations themselves have taken the initiative to report about ASEAN and ASEAN integration (that is beyond writing ASEAN news as under the foreign news sections). Most of the focus of these editorial initiatives is business, given the importance of the AEC pillar. The Bangkok Post of Thailand had introduced a weekly page on ASEAN matters to report about business and investment opportunities. BusinessMirror in the Philippines also has an ASEAN section in cooperation with a chamber of foreign business people. 
Stories on Southeast Asia are staple fare in regional news media outfits, such as Asia Times and Asian Correspondent (with operations based in Hong Kong and the United Kingdom, respectively). The Southeast Asian Globe magazine (www. sea-globe.com), a political magazine operating out of Siem Reap, Cambodia, has existed since 2009.

Through a continent-wide network of newspapers in Asia, the Asia News Network (ANN, funded by the German political foundation Konrad-AdenauerStiftung) frequently reports on Southeast Asia. Under the aegis of the British business newspaper The Financial Times, a 'digital research service' focusing on ASEAN investment themes was launched as a subsidiary media product: the $F T$ ASEAN Confidential (now renamed FT Confidential Research, covering China and ASEAN). Aimed at international investors, fund managers, corporations and finance professionals, this for-subscription service by FT shares journalistic analyses and data surrounding real estate, investment, consumption, manufacturing and trade in ASEAN (Financial Times, 2013).

With funding from the ASEAN Secretariat, the nonprofit Inter Press Service (IPS) has been operating a journalism fellowship and grants programme enticing ASEAN journalists to report about various development issues in the region. The project 'Reporting Development in ASEAN' (www.aseannews.net) sought to fill the gap of reporting on development issues in the region, in the context that there is little space for in-depth stories on what ASEAN does and how member-countries contribute to today's pursuit of integration (Son, 2013; also in Chongkittavorn, 2011a, 2011b).

D. Journalism education in ASEAN: Journalism education in ASEAN is growing in an era when journalism education is becoming globalised. However, accurate figures on how many journalism schools (to cover universities, colleges and institutes) are wanting. The 2008 World Journalism Education Census of the World Journalism Education Council (WJEC) lists 60 journalism schools found in six ASEAN countries, though since that time journalism schools have opened in other countries like Myanmar (RTT News, 2013). It is also noted that foreign universities have opened up branches in foreign countries, including Malaysia and Thailand, and among their degree programmes is journalism.

In terms of journalism education in the region, there are similarities and differences in ASEAN nations. Almost all institutions that offer degree programmes in journalism followed a Western model, mostly from the United States (Sarkar et al, 1990; Hwa \& Ramanathan, 2000). In addition, most of the journalism educators teaching in countries like Brunei, Indonesia and Malaysia studied in foreign countries, and the people involved in setting up journalism schools in Asia are also mostly Americans (Hwa \& Ramanathan, 2000). An exception is the Philippines, which has an active journalism education sector. 
Given press systems and political environments in varied Southeast Asian countries, government-owned media and journalism schools, compared to privately-owned ones, have the tendency to use informal ways to teach journalism or get constrained by the government. In the case of Brunei where the Department of Information takes control of the media, the department only conducts informal on-the-job training services for their staff. As for Indonesia, educators must follow the curriculum set by the government - thus making all educational institutions 'uniform' which is a constraint for privately-owned schools (Hwa \& Ramanathan, 2000).

If countries' political systems impact on news media practice (KonradAdenauer-Stiftung, 2015), so does the delivery of journalism education in some ASEAN countries. Vietnam, for example, teaches journalism - the most in-demand social science course in the country - aligned with the values of the Communist Party of Vietnam. This situation impacts even on pedagogy; while students are taught the tenets of the CPV, teaching journalism skills is done through in-classroom exercises and not immersions to the communities and news beats where students can gather and write stories. The Vietnamese government highly regulates the delivery of journalism programmes in universities (Nguyen, 2008). Malaysia had seen the immense growth of journalism schools. However, the teaching of journalism is still aligned to training students the required industry skills but not on developing students' critical thinking (Luan \& Hoon, 2008). The Philippines sees its journalism education enjoying the leverage of exercising a free press, up to the level of classroom exercises when students find stories from communities and news beats. English literacy is also a plus for overall Philippine journalism education. There are concerns, however, of matching industry's needs and universities' traits of (supposedly) process-based learning, the fusion of social sciences and humanities disciplines in journalism instruction. The quality of journalism instruction in various areas of the Philippines was also a concern (Gapasin, Mirandilla, San Pascual \& Sanqui, 2008). Regardless of the type of news media system and educational delivery, these three ASEAN countries' journalism education face common issues: students not having the reading habit leading them to know less about issues; competence of the English and national languages; limited industry involvement in journalism education (not just through students' internships); and journalism instructors with limited news media experience (Gapasin, Mirandilla, San Pascual \& Sanqui, 2008; Nguyen, 2008; Luan \& Hoon, 2008).

There have been nagging issues on journalism education in ASEAN countries, apart from those earlier mentioned (Sarkar et al, 1990; Hwa \& Ramanathan, 2000). Muppidi (2008), for his part, notes the following issues and concerns for Asian journalism education: a) Absence of a regulatory body to set standards on journalism education in some countries; b) Problems of the contents ( 'what should 
be taught') of journalism courses, given variances within countries (skills based versus liberal arts orientation or both); c) Confusion on the roles and functions of journalism in individual countries (watchdog versus propaganda arm of the state); d) No systematic procedure for process-based learning of journalism given the stress on output (i.e., the stories students produce); e) Limited resources and facilities; f) Lack of industry support for broad-based journalism education; and g) The production of journalists who are 'not necessarily well-trained' (p. 31). Hwa \& Ramanathan (2000), surveying communication programmes in ASEAN (including journalism programmes), found similar issues.

Ownership of the schools and universities that offer journalism degree programmes in Malaysia, Indonesia and Thailand are mostly government-owned, while the majority of those in the Philippines are privately-owned (Sarkar et al, 1990). Malaysia and Singapore offer up to a doctoral degree programme in journalism while the rest of Southeast Asia only offer bachelor's and master's degrees. Privately-run universities offering journalism programmes abound in the Philippines.

Admission requirements, processes and policies also contribute to the variation of journalism education in the ASEAN region. Even the argument between formal and non-formal education is implied since some countries focus more on skills training rather than contextual and academic knowledge, the latter which university-based journalism programmes provide (Sarkar et al., 1990; also in Gapasin, Mirandilla, San Pascual \& Sanqui, 2008).

Journalism schools had made attempts to bond as a regional network. An attempt was made at a UNESCO conference in 2009 when the UN agency's model curricula for journalism were presented. Another attempt was made last year at a workshop on integrating disaster risk reduction in journalism curricula. Both events were held in Manila, with the latter event seeing the informal creation of a Southeast Asian Journalism Educators Network (SEAJEN). The Manila-based Asian Institute of Journalism and Communication (AIJC) pushed for the creation of this journalism schools network in the region (Leoni, 2014).

Quality assurance had become a buzzword in global education, to the point that universities had become conscious of being ranked worldwide (even regionally). One of the firms doing world university rankings is Quacquarelli Symonds (QS). The trend of the rankings of ASEAN universities, at least for the 'Communication and Media Studies' discipline, is that the richer universities — especially those in Singapore - are on top (Quacquarelli Symonds, 2015). Except for the Philippines, the world-ranked ASEAN communication schools do not mind the freedom of the press conditions in their countries (Tables 1 and 2). What regional integration may push is not only the harmonisation of standards of educational quality assurance but the push for (particularly) journalism programmes to benchmark with the region's best. 
As regards employment, countries are now harmonising their nationallevel qualifications frameworks leading to the ASEAN Qualifications Reference Framework. This AQRF means that qualifications may be compared across countries covering senior schooling, technical and vocations education and higher education (Manzala, 2013). Eventually, skilled workers from ASEAN countries will freely move around the region and their credentials recognised by the labor ministries of member-countries.

On the part of education, an ASEAN Quality Assurance Framework for Higher Education (AQAFHE) is set to harmonise country-level assessments of the quality of education in universities (Pijano, 2014). Some even allayed fears that given the AQRF, higher education will be 'homogenised' and may disregard cultural diversity and uniqueness of programmes in ASEAN countries (Asian Institute of Journalism and Communication, 2015).

\section{Findings}

This section presents the implications and challenges of 'integrating' journalists and journalism schools in ASEAN. These take into account the verbalisations of respondents of what do the terms 'ASEAN integration', 'ASEAN community' and 'ASEAN journalism' mean. Items such as operationalising "integration" efforts by journalists and journalism schools, and roles of these actors under the milieu of

Table 1: Top ASEAN universities for communication/media studies

\begin{tabular}{|c|c|c|c|c|c|c|c|c|}
\hline \multirow[t]{2}{*}{ University } & \multicolumn{3}{|c|}{$\begin{array}{l}\text { World ranking, } \\
\text { communication }\end{array}$} & \multicolumn{2}{|c|}{$\begin{array}{l}\text { World university } \\
\text { ranking }\end{array}$} & \multicolumn{3}{|c|}{$\begin{array}{l}\text { Freedom of the press } \\
\text { index scores of relevant } \\
\text { countries }\end{array}$} \\
\hline & 2013 & 2014 & 2015 & $2013 / 14$ & 2014/15 & 2012 & 2013 & 2014 \\
\hline $\begin{array}{l}\text { National } \\
\text { University of } \\
\text { Singapore }\end{array}$ & 4 & 9 & 13 & 24 & 22 & $\begin{array}{l}\text { Not } \\
\text { free }\end{array}$ & $\begin{array}{l}\text { Not } \\
\text { free }\end{array}$ & $\begin{array}{l}\text { Not } \\
\text { free }\end{array}$ \\
\hline $\begin{array}{l}\text { Nanyang } \\
\text { Technological } \\
\text { University }\end{array}$ & 11 & 6 & 15 & 41 & 39 & $\begin{array}{l}\text { Not } \\
\text { free }\end{array}$ & $\begin{array}{l}\text { Not } \\
\text { free }\end{array}$ & $\begin{array}{l}\text { Not } \\
\text { free }\end{array}$ \\
\hline $\begin{array}{l}\text { Universiti Sains } \\
\text { Malaysia }\end{array}$ & - & $\begin{array}{l}101- \\
150\end{array}$ & - & 355 & 309 & $\begin{array}{l}\text { Not } \\
\text { free }\end{array}$ & $\begin{array}{l}\text { Not } \\
\text { free }\end{array}$ & $\begin{array}{l}\text { Not } \\
\text { free }\end{array}$ \\
\hline $\begin{array}{l}\text { Universiti Putra } \\
\text { Malaysia }\end{array}$ & $\begin{array}{l}151- \\
200\end{array}$ & $\begin{array}{l}151- \\
200\end{array}$ & - & $\begin{array}{l}411- \\
420\end{array}$ & 376 & $\begin{array}{l}\text { Not } \\
\text { free }\end{array}$ & $\begin{array}{l}\text { Not } \\
\text { free }\end{array}$ & $\begin{array}{l}\text { Not } \\
\text { free }\end{array}$ \\
\hline $\begin{array}{l}\text { Chulalongkorn } \\
\text { University }\end{array}$ & $\begin{array}{l}151- \\
200\end{array}$ & - & - & 239 & 243 & $\begin{array}{l}\text { Not } \\
\text { free }\end{array}$ & $\begin{array}{l}\text { Not } \\
\text { free }\end{array}$ & $\begin{array}{l}\text { Not } \\
\text { free }\end{array}$ \\
\hline $\begin{array}{l}\text { University of } \\
\text { the Philippines }\end{array}$ & - & - & $\begin{array}{l}151- \\
200\end{array}$ & 380 & 367 & $\begin{array}{l}\text { Partly } \\
\text { free }\end{array}$ & $\begin{array}{l}\text { Partly } \\
\text { free }\end{array}$ & $\begin{array}{l}\text { Partly } \\
\text { free }\end{array}$ \\
\hline
\end{tabular}

Source: Quacquarelli Symonds (2013 to 2015) 
regional integration are background material for the presentation of implications and challenges of 'integrating' journalists and journalism schools in ASEAN.

A. Meanings: Journalism educators interviewed clearly understood ASEAN integration, with some of them remarking that integration can be a "push factor' to help provide the socio-economic and cultural needs of Southeast Asians through information. Educators as well welcome regional integration as a mechanism to bridge people's understanding of individual countries' peculiarities, and of the bigger region. Journalists interviewed are, not surprisingly, aware of the ASEAN's nature: as a 'political and economic bloc', as a 'forum that can spread awareness about the differences [of countries], and an umbrella mechanism to ensure that differences are not misplaced... and disputes and misunderstandings resolved' (Respondent J2). The journalism educators also took note of the similarities and differences in individual countries' cultures and histories, and recognised how political systems in the individual countries impact on countries' press systems (which the educators affirmed as influenced by Western countries).

Journalist-respondents showed eagerness in having an 'integrated ASEAN media' (meaning, a harmonised news media reporting about Southeast Asia to individual ASEAN news media). The educators took a step further and floated the idea of an 'ASEAN media center'. At the basic level, there is still limited appreciation as to what 'ASEAN news' deeply means since such a concept is not yet developed, say the educator-respondents.

The journalist-respondents think that having an 'ASEAN media centre' or whatever form of integrated news media for the region can lead to the easier flow of regional/ASEAN country reports, without much cost (Respondent J1). This kind of a regional editorial set-up can also lead the sharing of news content and resources, thus helping the news media in individual countries spread awareness about ASEAN. The educators added that if such a 'news center' solely for the region exists, countries can send their representatives and journalism schools can cooperate with each other.

There were also interesting insights from educators and journalists on what 'ASEAN journalism is'. The educators think the concept of 'ASEAN journalism' is reporting about all the member-countries by forming a unified media network or system wherein participating journalists know and understand each membercountry. ASEAN journalism, for these educators, is also editorial production coming from ASEAN journalists themselves. Even the style of reporting that the concept of 'ASEAN journalism' brings about may have to be displayed to separate the ASEAN journalists from other journalists, with 'no traces' of the Western press influence (Respondent JE2).

Yet there is no 'ASEAN journalism' (Respondent JE3) because of the influence 
of the Western press and their philosophies. It is also in this perspective that the diversity of cultures reveals the challenge of operationalising the "ASEAN journalism' concept. Collectively, journalists in the region 'are not identified collectively' (Respondent J1) and, as a baseline, are journalists of individual countries. Even in a single country, what with its cultural and language diversity, it is difficult to forge a national identity (Respondent J1). At best, during international events like ASEAN summits when Southeast Asian journalists band together, they work as a team and respect each other (Respondent J4).

For a journalism-educator, if 'ASEAN journalism' were to fly off, the problems of fellow ASEAN nations is a paramount concern: 'The harmony of the society is more important than freedom of individual expression' (Respondent JE2). Another journalist-educator's remark seemed to reveal the character of how Southeast Asian nations conduct each other - as non-interfering — and the influence of the individual country's culture and press system: 'News media should not exaggerate or over-expose some unnecessary issues. They should instead practice peace journalism to avoid conflicts, especially in religion' (Respondent JE1).

B. Mechanisms: The answers from both journalists and journalism-educators point to having a regional media centre for a mechanism, and this mechanism funneling ASEAN-centric stories to individual member-countries.

Yet a concern is how ASEAN is portrayed in the individual countries' news media. What the Inter Press Service content analysis research (2014) did not show was if the stories were localised angles about ASEAN-level concerns. It seems that even with the craze ASEAN integration brought about, there is little appetite for news about what is happening in other ASEAN countries - and thus the approach is to treat the ASEAN story with a local angle so that national-level audiences connect with the report (Respondent J1). So highlighting the country of operation thus becomes a first priority for the Southeast Asian journalist (Respondent J5).

Journalism-educators, for their part, think that story angles may not only have to factor in the proximity of the news to the affected audience (i.e., Southeast Asian news audience). Other ASEAN-centric news values that have to be considered include: relevance of the story to the shared socio-historical background of the region; impact of the story to Southeast Asians; importance of the story to the common interests and needs of ASEAN citizens; and the unique identities of each ASEAN nation as news currency. But pragmatically, the journalists reporting about other ASEAN countries will bring in their own local orientation and disposition since covering their own nation "would be difficult or impossible to detach' (Respondent J1).

Apart from the editorial roles associated with having a 'regional journalism' concept, the journalism-educators interviewed ascribed five roles that ASEAN's 
journalism schools bring to the vision of regional integration - roles that even journalists, under the ambit of integration, can assert. These roles are: a) The voice of the voiceless, with journalism as a tool of power; b) The agitators of critical thinking unto students and news audiences, especially since audiences are no longer passive news consumers; c) The values teachers, taking into account journalism's role as a "public service" and journalists' adherence to press ethics; d) The competent practitioners and professionals, all of whom are equipped with skills and experience to present engaging reports locally and about the ASEAN; and e) The disseminators of regional news, a role that even journalism teachers (not just the journalist) may have to practise.

The designation of these regional 'roles' by the journalism-educators also challenges the journalism schools, if the journalism-educators are to be believed, to integrate the pursuit of media integration through the university system. Examples of mechanisms include having a course on ASEAN reporting in prevailing curricula, and awareness about the cultures and histories of Southeast Asian countries (through courses on Southeast Asia). As well, what may have to be expected is the 'standardisation' of journalism education programmes in the region (Respondent JE1) that can compete (Table 2) with the rest of the world. The journalism curriculum thus plays a role since, in recognising ASEAN eccentricities in journalism (and not just the traits of the Western press), Southeast Asian reporters can become more capable to write about regional integration with cultural diversity as backdrop.

The journalist-respondents even acknowledged the role of the schools system in raising ASEAN literacy, taking note of the limited knowledge of citizens about the region-even among journalists in individual countries (Respondents J1 and J3). With limited knowledge about ASEAN, journalists will encounter difficulties integrating background and context into ASEAN reports, and stereotyping of countries and their citizens may possibly happen.

C. Challenges: The various qualities of press systems and journalism educational systems in individual ASEAN countries are obvious challenges to operationalise media integration and a regional approach to journalism education. And the cultural and political backgrounds of countries are the systemic challenges present in such desires for regional integration by journalists and journalism schools.

Language is another visible challenge, say both journalist and journalism educator-respondents. Even what language to be used in the stories can be debated, as English can be spoken fluently in only three of the ten ASEAN-member countries. Another obvious challenge is limited resources of news media outfits owned by Southeast Asian nationals, or even sending correspondents to other ASEAN countries.

Regardless if the party involved is a news media outfit or a journalism school, respondents acknowledge the nationally-centric approach of these players as a 


\begin{tabular}{|c|c|c|c|c|}
\hline Country & $\begin{array}{l}\text { University communication/ } \\
\text { media studies, } 2015\end{array}$ & $\begin{array}{l}\text { QS } \\
\text { country } \\
\text { ranking }\end{array}$ & $\begin{array}{l}\text { QS world } \\
\text { ranking } \\
(2014 / 2015)\end{array}$ & $\begin{array}{l}\text { QS Asian } \\
\text { ranking } \\
2015\end{array}$ \\
\hline \multirow{5}{*}{ Indonesia } & University of Indonesia & 1 & 310 & 79 \\
\hline & Universitas Gadjah Mada & 2 & $551-600$ & 137 \\
\hline & Airlangga University & 3 & $701+$ & 147 \\
\hline & Universitas Negeri Makassar & 4 & - & - \\
\hline & University of Brawijaya & 5 & $701+$ & - \\
\hline \multirow{5}{*}{ Malaysia } & Universiti Malaya & 1 & 151 & 29 \\
\hline & Universiti Putra Malaysia & 2 & 376 & 66 \\
\hline & Universiti Sains Malaysia & 3 & 309 & 49 \\
\hline & $\begin{array}{l}\text { International Islamic University } \\
\text { Malaysia }\end{array}$ & 4 & $501-550$ & $151-200$ \\
\hline & Universiti Kebangsaan Malaysia & 5 & 259 & 56 \\
\hline \multirow{5}{*}{ Philippines } & $\begin{array}{l}\text { University of the Philippines } \\
\text { [151-200] }\end{array}$ & 1 & 367 & 70 \\
\hline & Ateneo de Manila University & 2 & $461-470$ & 114 \\
\hline & De la Salle University & 3 & $651-700$ & $151-200$ \\
\hline & $\begin{array}{l}\text { Polytechnic University of the } \\
\text { Philippines }\end{array}$ & 4 & - & - \\
\hline & University of Santo Tomas & 5 & $701+$ & 143 \\
\hline \multirow{5}{*}{ Singapore } & $\begin{array}{l}\text { National University of Singapore } \\
\text { [13] }\end{array}$ & 1 & 22 & 1 \\
\hline & $\begin{array}{l}\text { Nanyang Technological University } \\
\text { [15] }\end{array}$ & 2 & 39 & 4 \\
\hline & Singapore Management University & 3 & - & - \\
\hline & Nanyang Institute of Fine Arts & 4 & - & - \\
\hline & $\begin{array}{l}\text { DigiPen Institute of Technology } \\
\text { Singapore }\end{array}$ & 5 & - & - \\
\hline \multirow{5}{*}{ Thailand } & Chulalongkorn University & 1 & 243 & 53 \\
\hline & Kasetsart University & 2 & $651-700$ & $151-200$ \\
\hline & Mahidol University & 3 & 259 & 44 \\
\hline & Thammasat University & 4 & $601-650$ & 143 \\
\hline & Chiang Mai University & 5 & $501-550$ & 99 \\
\hline
\end{tabular}

Source: Quacquarelli Symonds (2015) 
challenge if ASEAN journalism wants to put as template the regional perspective in the reporting and editing of the stories and in the teaching of journalism. Taking this regional perspective into account, say journalism educators, will also have to capture people's interests.

Interestingly, a journalist-respondent thinks media ownership is a hurdle for media integration. This is since most of the ASEAN member-countries do not practice democracy, and these countries do not enjoy a free press. The respondent said: 'The biggest barrier will be the question of ownership, and the extent to which the media owners can guarantee editorial independence, a rare concept in most ASEAN countries' (Respondent J1).

\section{Discussion}

This article presented the views of some Southeast Asian journalists and journalism educators surrounding the opportunities and challenges of regional integration into the journalism sectors. The concept being analysed by this research is whether regional integration of news media systems and/or journalism education systems is probable.

The answers put forward by journalists and journalism-educators reveal the difficulties surrounding a regional approach towards journalism. These difficulties were seen also in other contexts, like in Africa (Churchill, 1991) and Europe (Russ-Mohl, 2003). Not even a common international language for these journalists (say, English or French as in the case of other countries) is enough to bridge journalists' and journalism schools' understanding of the region, its member-countries and these countries' socio-economic, political and cultural peculiarities. While the ASEAN is mobilising its mechanisms - per pillar (APSC, AEC and ASCC), and covering various aspects (e.g., trade, educational quality assurance, skills recognition) - in order to complete the seeds of regional integration, the journalism sector is still in the early stages of exploring what regional integration implies to individual and regional-level journalism.

It is interesting that respondents floated the concept of 'ASEAN journalism', in the premise that such editorial approach to journalism is tied to the search for a regional identity (even if specific to journalism). This concept, respondents themselves recognised however, takes into account the politics-media relationships in individual countries, and the collective disposition of ASEAN as a body of countries: non-interfering while trying to achieve consensus, but conscious of defending national sovereignty (Moorthy \& Benny, 2012; Milner, 2012). Respondents also presented varying allusions to what 'ASEAN journalism' is: a non-interfering approach to news reportage, voice of the voiceless, or agitators of critical thinking. These views reflect the journalistic cultures these journalists and educators came from.

Heikkilä and Kunelius' model (2006) looks at how journalists covering the 
European Union approach their coverage of the said regional grouping. Some of the views of this paper's respondents that 'ASEAN journalism' is absent because of the influence of the Western press may give the impression that the cosmopolitan discourse prevails in ASEAN news coverage. What some of these respondents may be looking for are journalists who carry classical professionalism or even secular discourses (leaning towards the nationalism quadrant of Heikkilä and Kunelius [Figure 1]): reporting about the region for audiences of that region. If the journalists of ASEAN do not want to pit ASEAN nations against each other (i.e., non-interference, that being the nature of ASEAN), a variant of a 'cosmopopular' discourse - done by journalists within the region - can emerge.

One can also sense from the respondents, especially the journalists, that there is a desire for a freer media even if they did not explicitly say that ASEAN integration can lead to such. Even the concept of an 'ASEAN media center' brought excitement to some respondents, even if the details of operationalising regional integration (e.g., skills recognition, harmonisation of degree programmes) as these affect journalists and journalism education are either less-known or not known to respondents.

What followed after discussing concepts of 'ASEAN journalists' and an 'ASEAN media centre' are the roles of ASEAN journalists in the era of regional integration. The roles journalism educator-respondents enumerated are notably tied to an individual country's journalism culture (Weaver \& Wilnat, 2012). Some ASEAN countries were part of a cross-country study on journalism cultures and roles; the top role of journalists in 'partly-free' Indonesia is 'be watchdog of government' versus the top role of 'reporting news quickly' by journalists from 'not free' countries Malaysia and Singapore (Weaver \& Wilnat, 2012; Freedom House, 2015). The results show Indonesia's leaning to the 'Fourth Estate' role of journalism in its democracy and less influence of political and economic forces, versus Malaysian journalists' recognition of restricted editorial autonomy and Singapore journalists' circumspect disposition as regards the press' relationship with the state and with the greater society (Weaver \& Wilnat, 2012). The interplay of these country-level roles and journalistic role conceptions of Southeast Asian journalists under the ambit of regional integration will thus be interesting. This is especially if some journalist-groups and some journalism schools in the region wish to 'operationalise' a regional media centre.

There is nothing surprising in the challenges enumerated by respondents in the road to media integration in ASEAN. From the responses also, if journalists and journalism schools do see opportunities (including economic, like increased readership, advertising and foreign student intake) from ASEAN integration, calibration of prevailing national-level practices to a regional perspective is a step forward for these players in the journalism sector.

No wonder that research on media and regional integration has yet to 
advance a theory or a framework that covers the entirety of journalism's place in regional integration. Heikkilä and Kunelius' model (2006) is a starting point. Salvosa (2014) then adopted Heikkilä and Kunelius' model and situated it to the case of business journalism and regional integration's economic opportunities. Yet regional groupings' search for a regional-wide (cultural) identity may be a constraint towards developing theoretical models. Further research on journalism and regional integration may have to reflect deeply on the overall place of the journalism sector in this regional approach. This is because people with limited awareness of regional integration may not realise the direct impacts of regional integration to them and to their countries. These impacts can be explained by journalists and their reportage of the geographic region and of individual countries.

For the meantime, journalists can operationally apply editorial strategies towards reporting on neighbouring countries, whether in individual countries or as a regional grouping. These can include news syndication of ASEAN stories; training of journalists from various beats (news, business, sports) on reporting about ASEAN; special editorial projects on ASEAN and its impact on, say, individual countries in areas like politics, the economy, business, foreign relations, etc.; cooperation between news organisations of various countries (like the model of the Asian News Network); among others. For a start, individual news sections or beats of an ASEAN-based news organisation will be simply broadened to capture news - on a regular basis, not just during annual ASEAN summits-from neighbouring countries (even up to the sports page). With regional integration (especially economic integration) beginning in 2015, an interesting study will be a follow-up content analysis of ASEAN reportage starting the said year (with the assumption that ASEAN integration fueled more reportage on ASEAN and on ASEAN countries).

The research acknowledges the limitation that researchers only interviewed a total of nine respondents across ASEAN. This reflected difficulties of getting respondents, especially journalists. Contrast this to the 149 semi-structured interviews Heikkilä and Kunelius (2006) conducted. Amid this methodological limitation, this paper is an exploratory attempt at analysing how a specific geographic region - with a disparate set of news media systems - will see its journalists and journalism schools work together.

\section{Conclusion}

Journalists and journalism schools in individual countries work together to help develop a country's news media system. The latter trains the would-be journalists while professionals help journalism schools train budding journalists as prospective members of the news workforce. Journalism schools also imbibe skills training, disciplinary rigor and critical thinking that are essential in daily journalistic practice. Within a country, depending on the prevailing news media 
system, these activities showcase the symbiotic relationship between journalists and journalism schools.

Now that individual countries belonging to a regional aggrupation are 'integrating', how then should country-level journalists and journalism schools respond? This was the thrust of this paper. As viewed from the answers of four journalists and five journalism educators, there is excitement and anxiety on the possibilities regional integration brings forth to journalists and to journalism schools. For now, journalists and journalism educators interviewed are attached to their country-level journalistic cultures and practices, not yet ready to work on 'integration'. Even the ASEAN itself has yet to see the role of journalism in regional integration (in Chongkittavorn, 2011a). It also remains early to see the economic benefits of an 'ASEAN-centered journalism' to the news media and to journalism schools.

For now, 'ASEAN-centered journalism' is operationally the reportage of regional issues (that may possibly be tied to the individual ASEAN country) and of issues affecting individual member-countries. What 'ASEAN-centered journalism' means remains unclear. It may imply that Southeast Asian journalists report on their own news given their individual country contexts, things that the Western press may not be able to see since these foreign journalists report on Southeast Asia for an international audience. 'ASEAN-centered journalism' may preliminarily cover how an event or issue in an individual Southeast Asian community impacts locally, on neighbouring countries, on the entire region, and even on countries outside of the immediate region of scope. For example, the current Philippine government's policy actions against drug users and pushers (as mandated by President Rodrigo Duterte) has motivated Indonesia to take similar measures. ASEAN however has yet to have a region-wide policy on curbing the drug menace, and on drug trafficking.

Having this multi-layered editorial approach to reporting about ASEAN can be the starting point for journalists and journalism schools to work together, not necessarily to 'integrate.' Journalism schools can offer courses on Southeast Asia to raise students' awareness on the region (e.g. University of Santo Tomas in the Philippines); professional journalism courses can then be about 'Southeast Asian reportage' (a single course) or have exercises in news and feature writing courses on Southeast Asian affairs. News organisations and journalism schools in individual countries can then collaborate to train current journalists and journalism students about Southeast Asian reportage. Country-level experiences can then be shared with fellow ASEAN countries. Stories on Southeast Asia by students and by journalists, especially if published and circulated, will then help raise awareness about ASEAN.

Recommendations such as curricular revisions, networking activities, cross-country reporting projects and researches, or even ethics training (given 
concerns over media corruption across ASEAN countries [Milton, 2015]), will be expected from the journalism sector in ASEAN member-countries. Prevailing Southeast Asian journalist-groups (e.g., SEAPA, CAJ, SEAJU) can still continue their work on improving the welfare of journalists, highlighting press freedom issues, further improving the skills of journalists in news gathering and writing (even specifically to reporting about ASEAN). Aspiring to a regional-level democratic press system can be envisioned, though this is a long-term project. The internet and social media can easily connect news audiences from different ASEAN countries, benefiting those producing and circulating ASEAN stories.

Regional-level journalism that operates under a milieu of diverse press systems is never an easy project. Southeast Asian journalists may be excited for a future - under regional integration — where the region's freedom of expression is more open. Having an 'ASEAN-centered journalism and journalism education' as a response of the journalism sector to regional integration will be a long-term goal. Practical projects in individual newsrooms and journalism schools are small but viable steps to moving to next levels of engagement that are regional (i.e., ASEAN) in scope. Future studies on regional integration and journalism may also help assess journalists' place and influence before a broader audience.

\section{References}

Adam, S. (2008). Do mass media portray Europe as a community? Javnost-The Public, 15(1), 91-112.

Arao, D. (2008). Reporting ASEAN: An assessment of the ASEAN news media and the ASEAN as a topic. Paper presented at InWEnt workshop, Jakarta, Indonesia, November 18.

Article 19 (2012). ECOWAS: Draft framework on freedom of expression and right to information. Dakar, Senegal.

ASEAN Secretariat (2008). The ASEAN Charter. Jakarta, Indonesia.

ASEAN Secretariat (2009). ASEAN Socio-Cultural Community Blueprint. Jakarta, Indonesia.

ASEAN Secretariat (2013). Surveys on ASEAN community building effort. Jakarta, Indonesia.

Asian Institute of Journalism and Communication (2015). Pinoy communicators should be ready for ASEAN integration. Retrieved from www.aijc.com.ph/content/article/14sample-data-articles/259-pinoy-comm.html

Carey, S., \& Burton, J. (2004). Research Note: The influence of the press in shaping public opinion towards the European Union in Britain. Political Studies, 52(3), 623-640.

Carlos, J. M. \& Cadiz, M. C. H. (2003). Centers of excellence in youth media education in ASEAN: The Philippine perspective. Singapore: Asian Media Information and Communication Centre and Nanyang Technological University-School of Communication and Information.

Cauwenberge, A. V., Gelders, D., \& Joris, W. (2009). Covering the European Union. Javnost-The Public, 16(4), 41-54.

Chaban N. \& Holland, M. (Eds.) (2008). The European Union and the Asia-Pacific: Media, public and elite perceptions of the EU. London, United Kingdom, \& New York, 
United States: Routledge.

Chongkittavorn, K. (2002). Southeast Asian media struggle to be free. Nieman Foundation for Journalists at Harvard: Nieman Reports. Retrieved from http://niemanreports.org/ articles/southeast-asian-media-struggle-to-be-free/

Chongkittavorn, K. (2011a). Media and civil society: Vital players ASEAN must embrace. The Nation. Retrieved from www.nationmultimedia.com/home/2011/09/19/opinion/ Media-and-civil-society-Vital-players-Asean-must-e-30165604.html

Chongkittavorn, K. (2011b). Chapter 7: Covering ASEAN for three decades. In Lee, Y. Y. (ed.). ASEAN matters: Reflecting on the Association of Southeast Asian Nations (pp. 39-42). Singapore: World Scientific Publishing.

Churchill, E. (1991). The mass media and regional integration in Africa. Africa Media Review, 5(1), 17-35.

Confederation of ASEAN Journalists. (n.d.). Confederation of Asian journalists (CAJ). Retrieved from www.nujm.org/nuj/content/archive/arc131125_01.pdf

De Vreese, C. (2001). Europe in the news: A cross-national comparative study of the news coverage of key EU events. European Union Politics, 2, 283-307.

De Vreese, C. \& Gleissner, M. (2005). News about the EU constitution: Journalistic challenges and media portrayal of the EU constitution. Journalism, 6(2), 221-242.

Deutsche Welle (2015). Media critical of Southeast Asian nations' handling of refugee crisis. Retrieved from www.dw.de/media-crtical-of-southeast-asian-nations-handlingof-refugee-crisis/a-1845688

Deuze, M. (2008). Journalism education in an era of globalization. In M. Löffelholz, D. Weaver, \& A. Schwarz (Eds.), Global Journalism Research: Theories, Methods, Findings, Future, (pp. 266-281). Massachusetts, MA: Blackwell Publishing Ltd.

Dursun-Ozkanca, O. (2011). European Union enlargement and British public opinion: The agenda-setting power of the press. Perspectives on European Politics \& Society, 12(2), 139-160.

Financial Times (2013). Financial Times launches ASEAN confidential. http://aboutus. ft.com/2013/05/02/financial-times-launches-asean-confidential/\#axzz3dej0H54S

Freedom House (2015). Freedom of the Press 2015 (Data). Retrieved from https:// freedomhouse.org/report/freedom-press/freedom-press-2015.

Gapasin, A. R., Mirandilla, K., San Pascual, M. R. \& Sanqui, D. C. (2008). Journalism education in the Philippines. Media Asia, 35(2), 101-109.

Gezgin, U. B. (2014). Regional journalism in Southeast Asia and ASEAN identity in making: Asia News Network as a case for international and intercultural communication. Istanbil Gelisim University Journal of Social Sciences, 1(1), 43-53.

Heikkilä, H., \& Kunelius, R. (2006). Journalists imagining the European public sphere. Javnost-The Public, 13(4), 63-79.

Hill, H. \& Menon, J. (2010). ASEAN Economic Integration: Features, fulfillments, failures and the future. ADB Working Paper Series on Regional Economic Integration No. 69. Manila, Philippines: Asian Development Bank.

Hwa, A. P. \& Ramanathan, S. (Eds.) (2000). Communication education in ASEAN (pp. 13-44). Singapore: Asian Media Information and Communication Centre.

Inter Press Service (2014). Reporting development in ASEAN. Singapore.

Jönsson, K. (2008). Unity-in-Diversity? Regional identity-building in Southeast Asia. Working Papers in Contemporary Asian Studies No. 29. Lund, Sweden: Centre for East and South-East Asian Studies, Lund University.

Jönsson, K. (2010). Regional identity-building in Southeast Asia. Journal of Current Southeast Asian Affairs, 29(2), 41-72. 
Konrad-Adenauer-Stiftung (2015). Asian media update. Retrieved from www.mediaupdate.org.

Lecheler, S. K., \& Hinrichsen, M. C. (2010). Role conceptions of Brussels correspondents from the new member states. Javnost-The Public, 17(1), 73-86.

Lent, J. (1981). The perpetual see-saw: Press freedom in the ASEAN countries. Human Rights Quarterly 3(1), 62-77.

Leoni, B. (2014). ASEAN push for DRR journalism syllabus. Retrieved from www. unisdr.org/archive/41064.

Lim, C. (2013). ASEAN media eye creation of press council. SunStar Cebu. Retrieved from http://archive.sunstar.com.ph/cebu/local-news/2013/05/25/asean-media-eyecreation-press-council-284087

Löffelholz, M. \& Arao, D. (2011). The ASEAN guide: A Journalist's handbook to regional integration in Southeast Asia. Bonn: German International Development Cooperation (GIZ) - International Institute for Journalism.

Luan, N. M. \& Hoon, L. L. (2008). Journalism Education in Malaysia. Media Asia $35(2), 84-100$.

Manzala, T. (2013). The ASEAN qualifications reference framework. Retrieved from ceap.org.ph/upload/download/20138/27222725873 1.pdf

Maslog, C. (1990). Communication education in Asia: Status and trends in India, Indonesia, Malaysia, Nepal, Philippines and Thailand. Manila, Philippines: Press Foundation of Asia.

Mensing, D. \& Franklin, B. (2011). Journalism education, training and employment. New York, United States: Routledge.

Milner, A. (2012). Studying ASEAN regionalism: What skillset is required? Retrieved from www.cseas.kyoto-u.ac.jp/edit/wp-content/uploads/2012/04/NL6510-14.pdf

Milton, R. (2015). ASEAN journalists: Still running scared from governments, still taking bribes. Penh Pal. Retrieved from http://penhpal.com/2015/04/asean-journalists-stillrunning-scared-from-governments-still-taking-bribes/

Muppidi, S. (2008). Summing up: Identifying generic problems and recommending solutions for improving the status and relevance of journalism education in Asia. Media Asia, 35(2), 131-132.

Nevis Pages (2014). CARICOM targets journalists to spread integration messages. Retrieved from www.nevispages.com/caricom-targets-journalists-to-spread-integration-message/

Nguyen, A. (2008). Journalism Education in Vietnam. Media Asia, 35(2), 110-130.

Opiniano, J. (2014). Journalism, journalism education and a region's integration. Presentation at the National Conference of the Philippine Association of Communication Educators (PACE), April 3-4, Benguet, Philippines.

Peter, J., \& De Vreese, C. H. (2004). In search of Europe-A cross-national comparative study of the European Union in national television news. Harvard Journal of Press/ Politics, 9(4), 3-24.

Pijano, C. (2014). ASEAN Quality Assurance Framework for Higher Education (AQAFHE). Retrieved from www.chea.org/pdf/2014_Presentations/ASEAN\%20Quality\%20 Assurance\%20Final-CIQG.pdf

Quacquarelli Symonds (2015). World university rankings. Retrieved from www.topuniversities.com.

Reang, P. (2014). Freedom of expression and right to information in ASEAN countries: A regional analysis of challenges, threats and opportunities. Retrieved from www. internews.org/sites/default/files/resources/InternewsEU_ASEAN_FoE_and_RTI_ Study_2014.pdf 
RTT News (2013). Myanmar, France sign media cooperation agreement. Retrieved from www.rttnews.com/2239558/myanmar-france-sign-media-cooperation-agreement.aspx

Russ-Mohl, S. (2003). Towards a European journalism? Limits, opportunities, challenges. Studies in Communication Sciences, 3(2), 203-216.

Sadasivan, V. (2010). Developing regional media collaborations for ASEAN community building: A keynote speech by Viswa Sadasivan. Keynote address at the second AMIC-ASEAN media forum, Bangkok 2010. Retrieved from http://amic.org.sg/ blog/2010/11/15/keynote-address-at-the-second-asean-media-forum-bangkok/

Saltmarsh, M. (2004). EU-Asian relations in the media. A practitioner's view. Asia Europe Journal, 2(1), 15-18.

Salvosa, F. II. (2014). ASEAN economic integration: Implications on news coverage. UST Journalism Working Paper Series, 2014/06. Manila, Philippines: University of Santo Tomas.

Sarkar, C., Suparto, I. R. M., bin Haji Adnan, M. H., Koirala, B. D., Maslog, C. C., \& Salayakanond, W. (1990). Communication education in Asia: Status and trends in India, Indonesia, Malaysia, Nepal, Philippines and Thailand. Manila, Philippines: Press Foundation of Asia.

Schneeberger, A. I. (2009). Constructing European identity through mediated difference: a content analysis of Turkey's EU accession process in the British press. Journal of Media and Communication, 1, 83-102.

SciDevNet (2012). Science journalism network for East Africa launched. Retrieved from www.scidev.net/global/communication/news/science-journalism-network-foreast-africa-launched.html

Sibanda, B. (2010). Journalism education in the Southern African development community region (SADC): 1989-2009. Presented at the Second World Journalism Education Congress (WJEC), July 5-7, Grahamstown, South Africa.

Skjerdal, T. \& Ngugi, C. M. (2007). Institutional and governmental challenges for journalism education in East Africa. Ecquid Novi: African Journalism Studies, 28(1-2), 176-189.

Slaatta, T. (2006). Europeanization and the news media: Issues and research imperatives. Javnost-The Public, 13(1), 7-23.

Son, J. (2013). Challenge: How to make ASEAN reporting sexier. Retrieved from www. aseannews.net/challenge-how-to-make-asean-reporting-sexier/

Southeast Asian Press Alliance (1997). About us. Retrieved from www.seapa.org/?page $\mathrm{id}=4684$

Southeast Asian Press Alliance. (2015). Laws suppressing media freedom in Southeast Asia. Retrieved from www.seapa.org/?p=10904

Stabroek News (2009). CARICOM not discussing licensing of journalists - Carrington. Retrieved from http://www.stabroeknews.com/2009/archives/11/02/caricom-notdiscussing-licensing-of-journalists-carrington/

Terzis, G. (2009). European journalism education. United Kingdom: Intellect.

Thompson, E. \& Thianthai, C. (2008). Attitudes and awareness toward ASEAN: Findings of a ten nation survey. Jakarta, Indonesia: ASEAN Foundation.

United Nations Educational, Scientific and Cultural Organization (2014). World trends in freedom of expression and media development: Regional overview of Asia and the Pacific. Paris, France: Author.

Vliegenthart, R., Schuck, A. T., Boomgaarden, H. G., \& De Vreese, C. H. (2008). News coverage and support for European integration, 1990-2006. International Journal of Public Opinion Research, 20(4), 415-439.

Wagstaff, J. (2010). Southeast Asian media: Patterns of production and consumption. (A 
survey of national media in 10 countries.) Retrieved from www.opensocietyfoundations.org/sites/default/files/production-consumption-20100212.pdf

Weaver, D. \& Wilnat, L. (2012). The global journalist in the 21st century. New York, NY: Routledge.

Williams, C. (2010). Journalists mull the efficacy of the CARICOM National Skills Certificate. The Daily Antigua Observer. Retrieved from http://antiguaobserver.com/ ournalists-mull-the-efficacy-of-the-caricom-skills-national-certificate/

World Journalism Education Council (2008). World Journalism Education Census.

Retrieved from http://wjec.ou.edu/programs.php

Jeremaiah Opiniano is assistant professor and coordinator of the journalism programme of the University of Santo Tomas (UST) in Manila, Philippines. He is also publisher of a community news organisation, The Filipino Connection (www. thefilipinoconnection.net). His research project colleagues Aira Leigh Bagtas, Karl Cedrick Basco, Ralph Joshua Hernandez, Elyssa Christine Lopez, Michael Carlo Rodolfo, Anne Kathleen Vicho are all Bachelor of Arts journalism graduates of the University of Santo Tomas. The authors would like to acknowledge the comments from Filipino editors Jose Ma. Carlos and Felipe Salvosa Il, both journalism lecturers at the University of Santo Tomas.

jmopiniano@ust.edu.ph 